Link article (Style APA): Bocheliuk, V. Yo. \& Panov M. S. (2020). The structural and functional model of the professional readaptation of the internally displaced persons. Insight: the psychological dimensions of society, 3, 84-96. DOI: 10.32999/2663-970X/2020-3-6

Link article (Style DSTU 8302: 2015): Bocheliuk, V. Yo. \& Panov M. S. The structural and functional model of the professional readaptation of the internally displaced persons. Insight: the psychological dimensions of society, 2020, 3, 84-96. DOI: 10.32999/2663-970X/2020-3-6

\title{
The structural and functional model of the professional readaptation of the internally displaced persons
}

\section{Структурно-функціональна модель професійної реадаптації внутрішньо переміщених осіб}

\author{
Received: April 02, 2020 Accepted: May 12, 2020
}

\author{
Bocheliuk Vitalii Yosypovych \\ Doctor of Psychological Sciences, Full \\ Professor, \\ Department of Social Work and Psychology \\ Zaporizhzhia Polytechnic National University, \\ Ukraine \\ vitalik.psyhol@ukr.net, \\ ORCID 0000-0001-8727-3818 \\ Panov Mykyta Serhiiovych \\ Candidate of Psychological Sciences, \\ Associate Professor \\ Department of Special Education \\ and Special Psychology \\ Municipal Institution of Higher Education \\ "Khortytsia National Educational \\ Rehabilitation Academy" \\ of Zaporizhzhia Regional Council, Ukraine \\ nikita.psyhol@ukr.net, \\ ORCID 0000-0002-5085-8895
}

\author{
Бочелюк Віталій Йосипович \\ доктор психологічних наук, професор, \\ кафедра соціальної роботи \\ та психології \\ Національний університет “Запорізька \\ політехніка", Україна \\ vitalik.psyhol@ukr.net, \\ ORCID 0000-0001-8727-3818 \\ Панов Микита Сергійович \\ кандидат психологічних наук, доцент \\ кафедра спеціальної педагогіки \\ та спеціальної психології \\ КЗВО “Хортицька національна \\ навчально-реабілітаційна академія" \\ Запорізької обласної ради, Україна \\ nikita.psyhol@ukr.net, \\ ORCID 0000-0002-5085-8895
}

\footnotetext{
Abstract

The purpose of the research is to develop and substantiate the structural and functional model of the professional readaptation of unemployed internally displaced persons. Methods. In the course of the study, the authors use a complex of methods, in particular, the analysis of legislative and regulatory documents which prescribe the rights and duties of internally displaced persons, scholarly literature dealing with the subject-matter of the article to identify the development status of the issue concerned and methodological and theoretical fundamentals
}

\begin{abstract}
Анотація
Мета статті - розробити й обгрунтувати структурно-функціональну модель професійної реадаптації безробітних, що належать до категорії внутрішньо переміщених осіб. Методи. У процесі дослідження використано комплекс методів, зокрема аналіз законодавчих і нормативно-правових документів, які визначають права й обов'язки внутрішньо переміщених осіб, наукової літератури 3 проблеми дослідження для визначення стану розроблення порушеного питання та методологічних і теоретичних засад дослідження; узагальнення й систематизації
\end{abstract}


of the research; generalization and systematization to draw the conclusions; modeling to create the structural and functional model. To perform the correctional and rehabilitation activity with unemployed belonging to the category of internally displaced persons effectively, the authors have chosen the methods which present the psychosocial model of rehabilitation (N. Sardzhveladze), the Nonviolent Communication model (M. Rosenberg) and psychosocial model of resilience development (M. Euwema). Results. In the process of creating the structural and functional model of the professional readaptation of unemployed internally displaced persons, it was formulated the three-level concept: the methodological level which elucidates the interrelations of scientific approaches in resolving the issue of concern; the theoretical level involves taking into account of advances of the contemporary psychology on the area of social readaptation; the practical level stipulates the development of conceptual and procedural support of the correctional and rehabilitation activity. The elaborated structural and functional model contains the following components, which have direct functional relations: purpose, content, tools and methods, expected result. The model consists of purposeful (purpose and tasks), theoretical-methodological (methodological approaches, general scientific and specific principles), conceptual-activity (content, forms, methods, means of professional readaptation) and criteria-performance (complex methods of diagnostics, criteria, indicators and levels of professional readaptation) blocks. Conclusions. The article develops and justifies the structural and functional model of the professional readaptation of unemployed internally displaced persons. The positional layout of its components, first, demonstrates the consistency of problem solution and, second, the reasoning of execution of correctional and rehabilitation activities. The research proves that interaction and interrelations of the formed and described blocks guarantee the cohesiveness, functionality and effectiveness of the proposed model of professional readaptation of internally displaced persons. The model also focuses on the optimization of the practical activity of experts who mentor the mentioned category of citizens.

Key words: unemployed, structural and functional model, forced migration, social readaptation, block.

\section{Introduction}

Over recent years, in the context of intensification of the external threat and some crisis processes in the life of Ukrainian society, new phenomena have emerged which require an adequate з метою формулювання висновків; моделювання для створення структурно-функціональної моделі. Для ефективного здійснення корекційно-реабілітаційної роботи з безробітними з категорії внутрішньо переміщених осіб обрано методики, що презентують психосоціальну модель реабілітації (Н. Сарджвеладзе), модель ненасильницького спілкування (М. Розенберг) та психосоціальну модель розвитку стійкості (М. Еувема). Результати. У процесі створення структурно-функціональної моделі професійної реадаптації безробітних з переліку внутрішньо переміщених осіб сформульовано концепцію, яка мала трирівневу структуру: методологічний рівень, що розкриває взаємозв'язки наукових підходів у розв'язанні проблеми; теоретичний, що передбачав врахування здобутків сучасної соціальної психології у сфері соціальної реадаптації; практичний, у межах якого відбувалося розроблення змістового і процесуального забезпечення корекційно-реабілітаційної роботи. Спроектована структурно-функціональна модель містить такі компоненти: мету, завдання, зміст, методики й методи, очікуваний результат, які перебувають у безпосередніх функціональних взаємозв'язках. Розроблена модель складається 3 цільового (мета й завдання), теоретико-методологічного (методологічні підходи, загальнонаукові і специфічні принципи), змістово-діяльнісного (зміст, форми, методи, засоби професійної реадаптації) і критеріально-результативного (комплексна методика діагностики, критерії, показники та рівні професійної реадаптації) блоків. Висновки. У статті розроблено й обгрунтовано структурно-функціональну модель професійної реадаптації безробітних, що належать до внутрішньо переміщених осіб, позиційне розташування компонентів якої, по-перше, відображає послідовність розв'язання проблеми, а по-друге, логіку здійснення корекційно-реабалітаційної роботи. Доведено, що взаємодія та взаємозв'язок усіх визначених та схарактеризованих блоків забезпечує цілісність, дієвість та ефективність запропонованої моделі професійної реадаптації безробітних, які належать до внутрішньо переміщених осіб, а також спрямована на оптимізацію практичної діяльності фахівців, які здійснюють супровід зазначеної категорії громадян.

Ключові слова: безробітні, структурно-функціональна модель, вимушена міграція, соціальна реадаптація, блок.

\section{Вступ}

Упродовж попередніх років, у зв'язку з активізацією зовнішньої загрози і низки кризових процесів у житті українського соціуму, з'являються нові явища, які потребують адекватного 
response from the state and society to resolve urgent and potential problems. One of such phenomena is internally displaced persons who lost housing, work, social status, and even were forced to change the sociocultural environment due to the annexation of the Crimean Peninsula by the Russian Federation and military actions in eastern Ukraine. The situation of forced internal migration causes the social maladaptation of an individual who is characterized by depressive positions, passivity, conformism, reluctance to address the issues of settlement, including professional, in the new conditions adequately. Art. 2 of the Law of Ukraine "On Ensuring Rights and Freedoms of Internally Displaced Persons" (2014) states: "Ukraine takes all possible measures under the Constitution and laws of Ukraine, international treaties ratified by the Verkhovna Rada of Ukraine to prevent possible internal displacements, to protect the rights and freedoms of internally displaced persons, to create conditions for voluntary returning of such persons to their previous residence places or further reintegrationat the new place of residence in Ukraine". Thus, there is a need to form a system of adaptation measures for social and, firstly, professional readaptation of the unemployed from the list of internally displaced persons.

In the course of the research, the authors take into account the scientific works of L. Orban-Lembryk (Orban-Lembryk, 2008), which analyze the impact of migration processes on the behavioral features of an individual; O. Blynova (Blynova, 2016) who marks the aspects of social and psychological adaptation of the forced migrants; K. Aksenchenko (Aksenchenko, 2018) who highlights the psychological features of the human behavior under conditions of unemployment; I. Drozdova (Drozdova, 2016) who elaborates the methods of psychological support of forced migrants; as well as papers of G. Gaida, (Gaida, 2015) concerning the social and professional adaptation of workers. However, as of today, there are no comprehensive scientific papers devoted to the issue of professional rehabilitation of the unemployed, who belong to the category of internally displaced persons.The theoretical and practical significance of the problem under consideration determines the relevance of the undertaken research.

The purpose of the article is to develop and substantiate the structural and functional реагування з боку держави й суспільства для розв'язання нагальних і потенційних проблем. Одним із таких феноменів $\epsilon$ внутрішньо переміщені особи, які у зв'язку з анексією Російською Федерацією Кримського півострова і воєнних дій на Сході України втратили житло, роботу, соціальний статус, подекуди були змушені змінити соціокультурне оточення. Ситуація вимушеної внутрішньої міграції призводить до соціальної дезадаптації особистості, ознаками якої $€$ депресивні стани, пасивність, конформізм, неготовність адекватно вирішувати проблеми облаштування, зокрема професійного, у нових умовах. У ст. 2 Закону України "Про забезпечення прав і свобод внутрішньо переміщених осіб” (2014) зазначено: “Україна вживає всіх можливих заходів, передбачених Конституцією та законами України, міжнародними договорами, згода на обов'язковість яких надана Верховною Радою України, щодо запобігання виникненню передумов вимушеного внутрішнього переміщення осіб, захисту та дотримання прав і свобод внутрішньо переміщених осіб, створення умов для добровільного повернення таких осіб до покинутого місця проживання або інтеграції за новим місцем проживання в Україні". Відтак, постає необхідність налагодження системи адаптаційних заходів з метою соціальної, а насамперед професійної, реадаптації безробітних з переліку внутрішньо переміщених осіб.

У процесі дослідження взято до уваги наукові праці Л. Орбан-Лембрик (Орбан-Лембрик, 2008), у яких проаналізовано вплив міграційних процесів на поведінкові прояви особистості; О. Блинової (Блинова, 2016), у яких визначено особливості соціально-психологічної адаптації вимушених мігрантів; К. Аксенченко (Аксенченко, 2018) про психологічні особливості поведінки особистості в умовах безробіття; І. Дроздової (Дроздова, 2016) про методи психологічної допомоги вимушеним мігрантам; Дж. Гайда (Gajda, 2015) про соціальну й професійну адаптацію працівників. Проте на сьогодні відсутні комплексні наукові праці, присвячені проблемі професійної реадаптації безробітних, що належать до категорії внутрішньо переміщених осіб. Теоретична і практична значущість зазначеної проблеми і зумовила актуальність проведеного дослідження.

Мета статті - розробити й обгрунтувати структурно-функціональну модель професійної реадаптації безробітних, що належать до категорії внутрішньо переміщених 
model of the professional readaptation of unemployed belonging to the category of internally displaced persons. The specified purpose involves realizing some research tasks as follows: to characterize the framework of categories and concepts of the study; to formulate the concept of the development of the structural and functional model; to present the structural and functional model of the professional readaptation of unemployed belonging to the category of internally displaced persons and to describe its structure.

\section{Methodology}

In the process of the scientific search for the formulation of theoretical fundamentals and the elaboration of a system of correctional and rehabilitation means, the authors examine some provisions of humanistic and existentialistic methodological approaches in terms of their complementarity. In particular, the implementation of the humanistic approach the basic principles of which were specified in the papers of C. Rogers (Rogers, 1942), A. Maslow (Maslow, 1944), R. May (May, 1977) makes it possible to integrate the crisis experience of internally displaced persons and to find ways of the use of available potential for updating the internal resources of a personality. The use of the ideas of the existentialistic approach - one of its theorists is I. Yalom (Yalom, 1999) - is expedient while elaborating individual programs for professional readaptation of unemployed internally displaced persons, because the representatives of this approach are against depersonalized therapy believing that each person should be treated individually taking into account his personal qualities and life situation.

In the context of the research, the authors use a complex of methods, in particular, the analysis of legislative and regulatory documents which prescribe the rights and duties of internally displaced persons; analysis of scholarly literature dealing with the subject-matter of the article to identify the development status of the issue concerned and methodological and theoretical fundamentals of the research; generalization and systematization to draw the conclusions; modeling to create the structural and functional model.

To perform the correctional and rehabilitation activity with unemployed belonging to the category of internally displaced persons, it was chosen the following methods: "Psychosocial model осіб. Зазначена мета передбачала реалізацію низки дослідницьких завдань: схарактеризувати категоріально-понятійний апарат дослідження; сформулювати концепцію побудови структурно-функціональної моделі; подати структурно-функціональну модель професійної реадаптації безробітних, що належать до категорії внутрішньо переміщених осіб, описати її структуру.

\section{Методологія}

У процесі наукового пошуку для формулювання теоретичних засад і розроблення системи корекційно-реабілітаційних заходів було взято до уваги окремі положення гуманістичного й екзистенціального методологічних підходів на основі їхньої взаємодоповнюваності. Зокрема реалізація гуманістичного підходу, основні засади якого були визначені в працях К. Роджерса (Rogers, 1942), А. Маслоу (Maslow, 1944), Р. Мея (Мау, 1977), дала змогу інтегрувати кризовий досвід внутрішньо переміщених осіб і визначити шляхи використання наявного потенціалу для актуалізації внутрішніх ресурсів особистості. Використання положень екзистенціального підходу, одним із теоретиків якого є I. Ялом (Yalom, 1999), стало доцільним у процесі розроблення індивідуальних програм з професійної реадаптації безробітних з переліку внутрішньо переміщених осіб, оскільки представники цього підходу виступають проти деперсоналізованої терапії, зважаючи, що до кожної людини потрібно знаходити підхід, зважаючи на її особистісні риси та життєву ситуацію.

Під час дослідження було використано комплекс методів, зокрема аналіз законодавчих і нормативно-правових документів, які визначають права й обов'язки внутрішньо переміщених осіб; аналіз наукової літератури з проблеми дослідження для визначення стану розроблення порушеного питання та методологічних і теоретичних засад дослідження; узагальнення й систематизації з метою формулювання висновків; моделювання для створення структурно-функціональної моделі професійної реадаптації безробітних з переліку внутрішньо переміщених осіб.

Для корекційно-реабілітаційної роботи 3 безробітними з категорії внутрішньо переміщених осіб обрано такі методики: “Психосоціальна модель реабілітації” Н. Сарджвеладзе (Сарджвеладзе, 2007), “Модель ненасильницького спілкування" (NVC-Nonverbal Communication) M. Розенберга (Розенберг, 
of rehabilitation of N. Sardzhveladze (Sardzhveladze, 2007), "The Model of Nonviolent Communication (NVC) of M. Rosenberg (Rosenberg, 2009) and "Psychosocial Model of Resilience Development of M. Euwema (Euwema, 2016).

\section{Results}

K. Aksenchenko associates professional readaptation of unemployed with the professional crisis which the scientist considers as a mental condition caused by unbalancing, disorganization or loss of contacts with the professional environment or labor activity; this condition can be triggered externally or by the very individual and characterized by changes in his mental psychological well-being, social, professional and financial status, as well as accompanied by mental tension and stress (Aksenchenko, 2018). A. Shumeiko states the professional readaptation is administratively adjusted by the state process of formation of the educational and professional sphere of acquisition or renewal of skills necessary for mastering professions, which have the greatest commercial demand in the modern labor market. Within the framework of this phenomenon, the researcher marks the state-guaranteed and practically implemented mechanism for the improvement of the available professional skill of a personality (Shumeiko, 2017). In the authors' opinion, professional readaptation should be considered as a gradual adjustment of workers, who have experience in labor activities, to new conditions of professional engagement (social relations, professional duties, physical conditions of labor, production objectives and operations) whereby the restructuring of need-motivational sphere of an individual takes place. Effectiveness index of professional readaptation is a balance between adaptation potential of an individual and his new professional activity (a person unlocks his professional potential, keeps up mental health and achieves professional success). The before mentioned gives grounds to conclude that professional readaptation is very important for the socio-cultural integration of the forced migrants because it is one of the key indicators of their effectual social adaptation in the new environment. I. Baklytskyi thinks that the effectiveness of professional adaptation can be assessed based on three diagnostic characteristics: the level of emotional tension and stress
2009), “Психосоціальна модель розвитку стійкості” М. Еувема (Еувема, 2016).

\section{Результати дослідження}

К. Аксенченко пов'язує професійну реадаптацію безробітних з професійною кризою, яку дослідниця розглядає як психічний стан, зумовлений розбалансуванням, дезорганізацією або втратою зв'язків із професійним середовищем або трудовою діяльністю; цей стан може ініціюватися ззовні або самою особистістю, характеризуватися змінами у її психологічному благополуччі, соціальному, професійному і матеріальному статусі, супроводжуватися психічною напруженістю і переживаннями (Аксенченко, 2018). А. Шумейко вважає, що професійна реадаптація - адміністративно скорегований державою процес формування освітньо-професійної сфери набуття чи відновлення навичок, необхідних для опанування професій, які мають найбільший комерційний запит на сучасному ринку праці. Дослідник виокремлює в межах цього явища гарантований державою та практично реалізований механізм підвищення вже існуючої виробничої кваліфікації особистості (Шумейко, 2017). На нашу думку, під професійною реадаптацією варто розглядати поступове пристосування працівників, які вже мають досвід трудової діяльності, до нових умов професійної діяльності (соціальних відносин, професійних обов'язків, фізичних умов праці, виробничих завдань та операцій), при якому відбувається перебудова потребово-мотиваційної сфери особистості. Показником ефективності професійної реадаптації $\epsilon$ баланс між адаптаційним потенціалом особистості та їі новою професійною діяльністю (людина реалізує свій професійний потенціал, зберігає психічне здоров'я, досягає професійного успіху). Це дає підстави для висновку, що професійна реадаптація дуже важлива для соціокультурної інтеграції вимушених мігрантів, оскільки вона $є$ одним із важливих показників їхньої успішної соціальної адаптації в новому середовищі. I. Баклицький зазначає, що ефективність професійної адаптації можна визначити на основі таких діагностичних характеристик: рівень емоційної напруги і стійкість до стресу; особливості мікросоціальної взаємодії і міри адекватності міжособистісних стосунків; енергетичний потенціал і здатність до логічного структурування ситуації (Баклицький, 2008). Для фіксації і відслідковування динаміки зазначених характеристик потрібно 
resilience; features of micro-social interaction and measure of the adequacy of interpersonal relations; energy potential and capacity for logical structuring of the situation (I. Baklytskyi). To fix and monitor the dynamics of the characteristics, it is essential to formulate theoretical fundamentals and to elaborate practical recommendations for professional readaptation of the mentioned category of the population, as well as to choose diagnostic tools. Consequently, the authors create the structural and functional model of professional readaptation of unemployed internally displaced persons which has the three-level structure:

- the methodological level covers the interrelations of different scientific approaches to the settlement of the problem of professional readaptation of unemployed belonging to internally displaced persons. The authors highlight that effectiveness and consistency of the solution of the relevant issue is ensured by the mutually correlated application of humanistic and existential approaches. This makes it possible to manage the issue concerned holistically, to take into account personal and social stress factors, to choose methods for psychotherapeutic work with forced immigrants;

- the theoretical level prescribes the analysis of scientific best practices in social psychology in general and the issue of social readaptation of different categories of the population. In particular, based on the analysis of findings of foreign scientists dealing with the issue of social readaptation, L. Orban-Lembryk specifies three basic scientific approaches to the problem: from the perspective of social identification (the focus is on self-perception and new environment in terms of available information); in the light of stress and a search for ways of its coping (compared to voluntary migration, forced one is treated as a stress situation, and the models of stress situations and possible options of getting out are studied); in the sociocultural context (the emphasis is placed on the psychology of intercultural contacts, shaping skills and abilities which facilitate the adaptation in the new environment) (L. Orban-Lembryk, 2018).

Moreover, under the framework of the theoretical level, the paper substantiates the framework of categories and concepts of the research (the concepts "adaptation", "readaptation", "professional readaptation", "internally displaced per- сформулювати теоретичні засади і розробити практичні рекомендації щодо професійної реадаптації зазначеної категорії населення, а також підібрати діагностичний інструментарій. 3 цією метою було створено структурно-функціональну модель професійної реадаптації безробітних з переліку внутрішньо переміщених осіб, загальна концепція побудови якої має трирівневу структуру:

- методологічний рівень розкриває взаємозв'язки різних наукових підходів до розв'язання проблеми професійної реадаптації безробітних з переліку внутрішньо переміщених осіб. Наголосимо, що ефективність і системність вирішення зазначеного питання забезпечується взаємоузгодженим застосуванням гуманістичного й екзистенціального підходів. Це дало змогу комплексно підійти до розв'язання досліджуваного питання, врахувати особистісні й соціальні стресогенні чинники, відібрати методики для психотерапевтичної роботи з вимушеними мігрантами;

- теоретичний рівень передбачав аналіз наукових напрацювань з соціальної психології загалом і з проблеми соціальної реадаптації різних категорій населення. Зокрема Л. Орбан-Лембрик на основі аналізу праць зарубіжних дослідників з проблеми соціальної реадаптації виділила три основні наукові підходи до цієї проблеми: 3 точки зору соціальної ідентифікації (увага сконцентрована на сприйнятті себе й нового оточення на основі наявної інформації); 3 урахуванням стресу та пошуку шляхів його подолання (вимушену міграцію, на відміну від добровільної, розглядають як ситуацію стресу, вивчають моделі стресових ситуацій і варіанти виходу з них); у соціокультурному контексті (увага акцентується на психології міжкультурних контактів, формуванні умінь і навичок, які сприяютьадаптаціївновомусередовищі)(ОрбанЛембрик, 2008).

Окрім того, у межах теоретичного рівня було обгрунтовано категоріально-понятійний апарат дослідження (поняття "адаптація", "реадаптація”, “професійна реадаптація", “внутрішньо переміщені особи”, “вимушена міграція” тощо), проаналізовано структуру досліджуваного феномена, розкрито сутність, зміст, етапи, закономірності і принципи професійної реадаптації безробітних з переліку внутрішньо переміщених осіб.

- практичний рівень, що передбачав моделювання й експериментальну перевірку системи корекційно-реабілітаційних заходів 
sons", "forced migration" etc.), analyzes the structure of phenomenon under study, elucidates the essence, content, stages, regularities and principles of professional readaptation of unemployed internally displaced persons.

- the practical level provides for modeling and experimental check of the system of correctional and rehabilitation activities on professional readaptation of unemployed belonging to internally displaced persons, the elaboration of conceptual and procedural, academic, assessment and diagnostic support of this process.

In addition, in the course of the research, the authors formulate some principal scientific and theoretical provisions which determine the essence of the designed model of professional readaptation of unemployed internally displaced persons. First, the model aims to pool efforts of experts acting in different spheres (representatives of public authorities, non-governmental and voluntary organizations, social care teachers, psychologists etc.) as well as contributes to the active cooperation of some public and non-governmental establishments, which carry out complex mentorship of the mentioned category. Second, the model has not only theoretical but also practical significance because relates to the direct practices of social rehabilitation institutions which perform mentorship and support of internally displaced persons - it has been tested in the real conditions. Third, the model complies with such basic requirements as the conceptual role, consistency, controllability, effectiveness, optimality and innovativeness. Fourth, the model can be transformed by gearing to volatile conditions as it is based on the components of the universal nature.

In general, the projecting of the structural and functional model of professional readaptation of unemployed internally displaced persons involves the covering of the following components which have direct functional ties: the purpose, tasks, content, structural components of professional readaptation, end points. The results of the analysis of scientific literature dealing with the subject-matter and study of the current state of the practice of professional readaptation of unemployed internally displaced persons allow building the structural and functional model which consists of purposeful, theoretical-methodological, conceptual-activity and criteria-performance blocks represented in the scheme (Fig. 1). з професійної реадаптації безробітних з переліку внутрішньо переміщених осіб, розроблення змістово-процесуального, навчально-методичного, оцінювально-діагностичного забезпечення цього процесу.

Окрім того, у процесі дослідження сформульовано низку принципових науково-теоретичних положень, які визначають сутність розробленої моделі професійної реадаптації безробітних $з$ переліку внутрішньо переміщених осіб. По-перше, запропонована модель спрямована на об'єднання зусиль фахівців різних напрямів (представників органів державної влади, громадських і волонтерських організацій, соціальних педагогів, психологів тощо), а також сприяє активній співпраці різних державних і громадських установ, які здійснюють комплексний супровід зазначеної категорії населення. По-друге, зазначена модель має не тільки теоретичне, але й конкретно практичне значення, тому що пов'язана з безпосередньою практикою роботи соціальних реабілітаційних установ, які здійснюють супровід і підтримку внутрішньо переміщених осіб, вона була апробована в реальних умовах. По-третє, модель відповідає таким основним технологічним вимогам: концептуальність, системність, керованість, ефективність, оптимальність, інноваційність. По-четверте, розроблену модель можна трансформувати, адаптуючи до змінних умов, оскільки вона заснована на компонентах універсального характеру.

У цілому проектування структурно-функціональної моделі професійної реадаптації безробітних $з$ переліку внутрішньо переміщених осіб передбачало відображення таких iї компонентів: мети, завдань, змісту, структурних компонентів професійної реадаптації, їі очікуваного результату, які перебувають у безпосередніх функціональних взаємозв'язках. Результати аналізу наукової літератури 3 проблеми дослідження та вивчення сучасного стану практики професійної реадаптації безробітних, що належать до категорії внутрішньо переміщених осіб дали змогу побудувати структурно-функціональну модель, яка складається 3 цільового, теоретико-методологічного, змістово-діяльнісного і критеріально-результативного блоків, що відображено на схемі (рис. 1).

\section{Дискусія}

Цільовий блок містить мету (організувати й здійснити професійну реадаптацію безробітних з переліку внутрішньо переміщених осіб), 
The structural and functional model of the professional readaptation of the internally displaced persons

INSIGHT

The Psychological Dimensions of Society

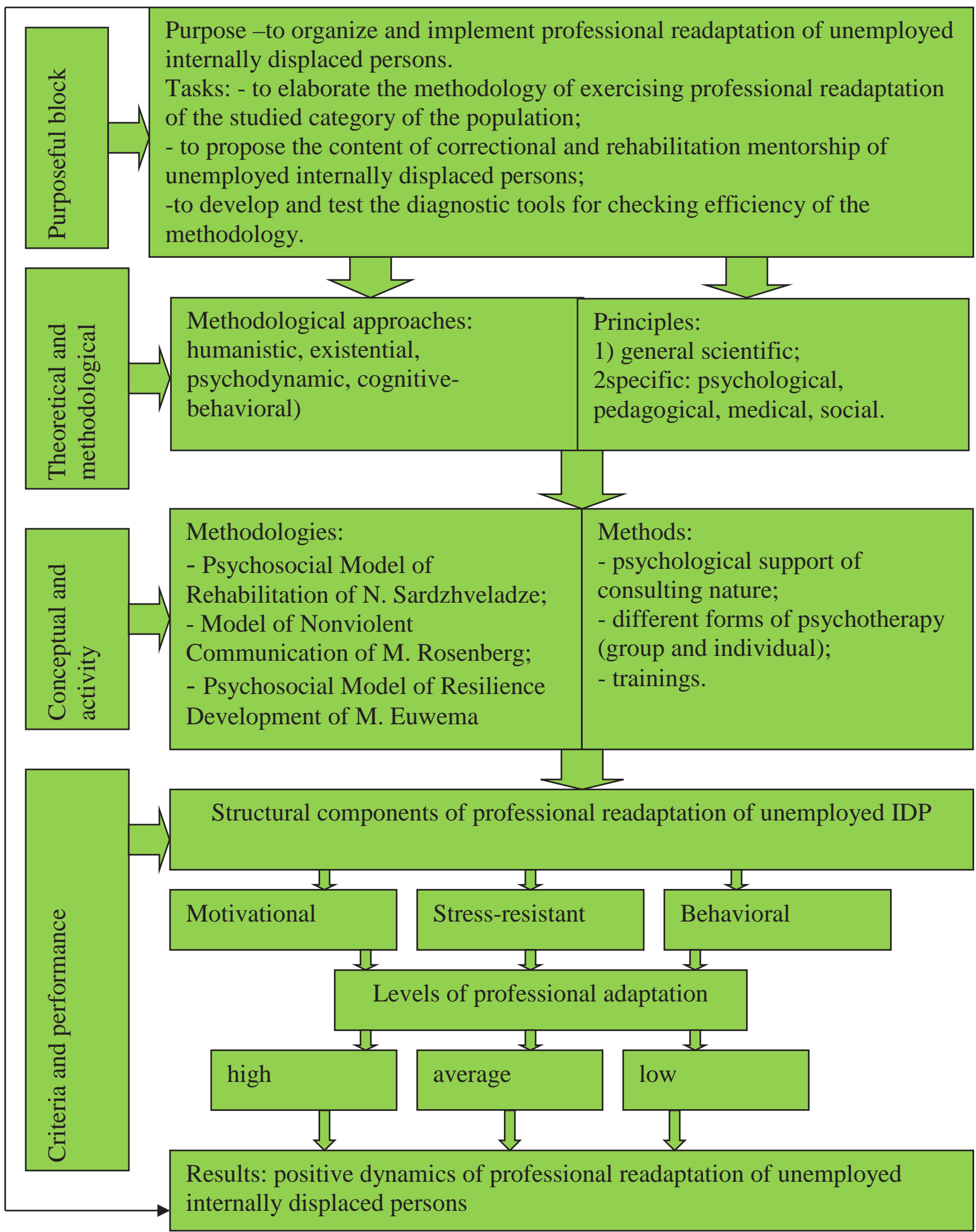

Fig. 1. The structural and functional model of professional readaptation of unemployed internally displaced persons 


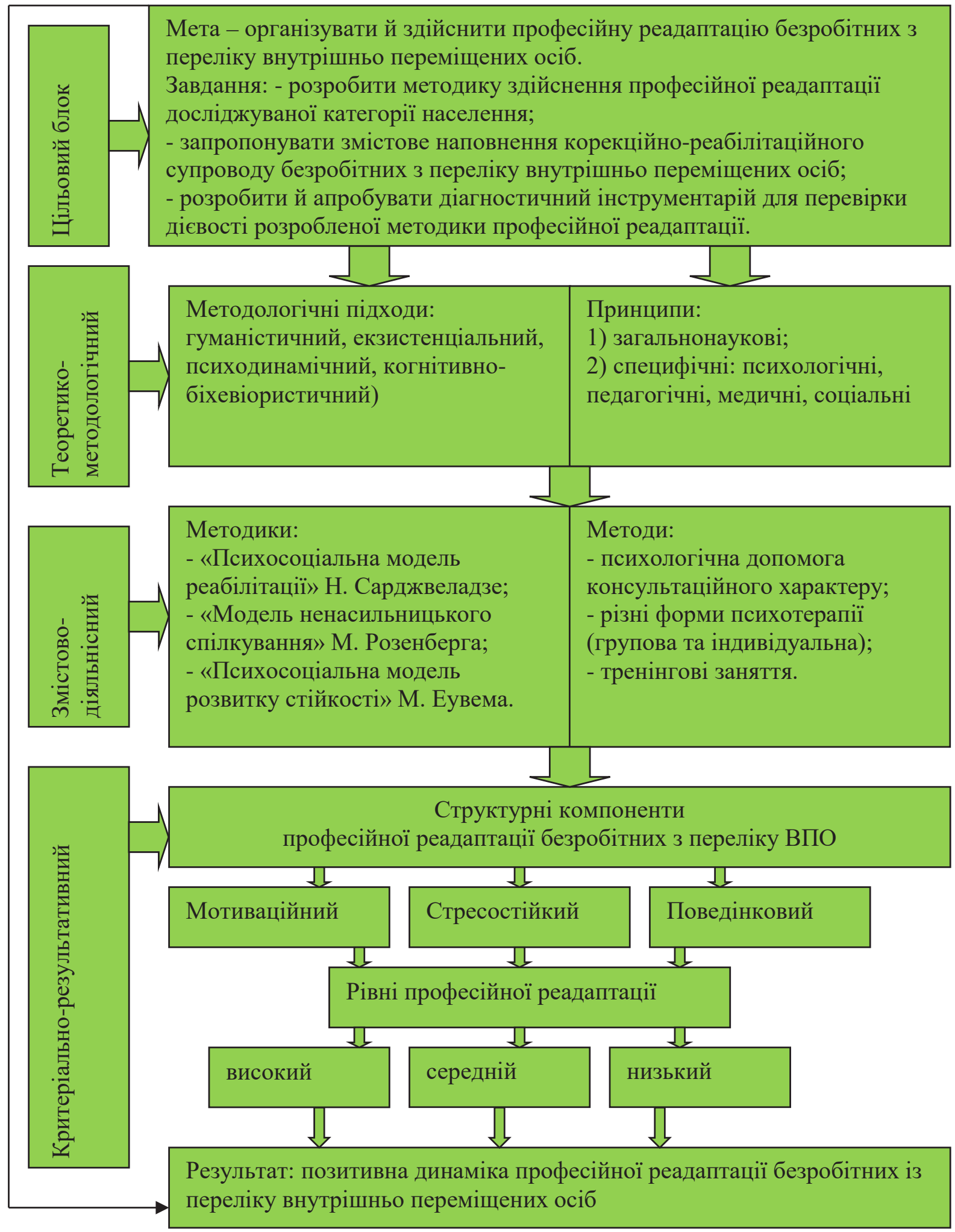

Рис. 1. Структурно-функціональна модель професійної реадаптації безробітних, що належать до внутрішньо переміщених осіб 


\section{Discussion}

The purposeful block includes the aim (to organize and to implement professional readaptation of unemployed internally displaced persons) which is specified through the tasks: to elaborate methodology of exercising professional readaptation of the studied category of the population; to propose the content of correctional and rehabilitation mentorship of unemployed internally displaced persons; to develop and test the diagnostic tools for checking the efficiency of the methodology.

The theoretical-methodological block consists of methodological approaches (humanistic and existential) and principles: general scientific (integrity, continuity, consistency, continuousness, differentiation) as well as specific, in particular, psychological (promptness, individual approach, the quality of comprising multiple stages, flexibility), social (integrity, continuousness, harmoniousness, dynamism, synergy), medical (maximum cooperation, multilevel nature of sanogenic measures), pedagogical (interaction of experts of different areas, systematization, humanization, individualization, provision of pedagogical support).

The conceptual-activity block of the structural and functional model has an algorithm of implementation of effective correctional and rehabilitation process; it embraces the conceptual and procedural aspects of activities focused on the professional readaptation of unemployed internally displaced persons.

During the elaboration of the methodology of professional readaptation of the mentioned category of the population, the authors take into consideration, first, foreign experience and tested foreign models of rehabilitation; second, the specifics of unemployed internally displaced persons as a special category differing by peculiar psychological problems: the availability of neurotic reactions; psychosomatic disorders; emotional and behavioral disturbances as well as disruption of relationships with the family and close environment.

Among the range of developed methodologies, the authors chose ones which address to psychosocial factors of the influence on unemployed internally displaced persons and dynamics of their maladaptation; formation of adaptation resource potential upon the condition of the change of social environment (internal migration). One яку було конкретизовано через такі завдання: розробити методику здійснення професійної реадаптації досліджуваної категорії населення; запропонувати змістове наповнення корекційно-реабілітаційного супроводу безробітних з переліку внутрішньо переміщених осіб; розробити й апробувати діагностичний інструментарій для перевірки дієвості розробленої методики.

Теоретико-методологічний блок складають методологічні підходи (гуманістичний, та екзистенціальний) та принципи: загальнонаукові (комплексності, наступності, послідовності, безперервності, диференційованості), а також специфічні, зокрема психологічні (оперативності, індивідуального підходу, багатоетапності, гнучкості), соціальні (цілісності, неперервності, гармонійності, динамічності, синергетичності), медичні (максимального співробітництва, багаторівневого характеру саногенних заходів), педагогічні (взаємодії фахівців різних напрямів, системності, гуманізації, індивідуалізації, забезпечення педагогічної підтримки).

Змістово-діяльнісний блок структурно-функціональної моделі містить алгоритм реалізації ефективного корекційно-реабілітаційного процесу; він охоплює змістові і процесуальні аспекти діяльності, спрямованої на професійну реадаптацію безробітних з переліку внутрішньо переміщених осіб.

У процесі розроблення методики професійної реадаптації зазначеної категорії населення було взято до уваги, по-перше, зарубіжний досвід та апробовані зарубіжні моделі реабілітації, по-друге, специфіку безробітних 3 переліку внутрішньо переміщених осіб, як особливої категорії, що вирізняється специфічними психологічними проблемами: наявністю невротичних реакцій; психосоматичних розладів; емоційними та поведінковими порушеннями, а також порушенням взаємин у сім'ї та близькому оточенні.

Серед розроблених методик реадаптації було обрано ті, які враховують психосоціальні чинники впливу на безробітних з переліку внутрішньо переміщених осіб та динаміку їхньої дезадаптації; формування адаптаційного ресурсного потенціалу за умови зміни соціального середовища (внутрішньої міграції). Однією з основних стала «Психосоціальна модель реабілітації», розроблена Н. Сарджвеладзе, метою якої було відновлення нормального соціального й побутового життя людини, іiі духовного світу. Для цього залученим фахів- 
of the principal methodologies is "Psychosocial model of rehabilitation" of N. Sardzhveladze, which aims to renew the normal social and everyday life of an individual, his inner world. For this reason, it is important for involved experts to have an idea on basic attitudes, worldview of an individual which have significantly changed due to internal migration and need for thorough recognizing and correcting. Thus, rehabilitation activities with unemployed internally displaced persons are directed at coping stress, personal development and their integration to new sociocultural conditions (Sardzhveladze, 2007).

Another methodology is "Psychosocial Model of Resilience Development" of M. Euwema which is based on the concept "resilience" and considered as a universal ability that empowers a person to minimize or to overcome negative consequences of some life cataclysms. Despite all trials and tribulations in the lives of forced migrants, they can rely both on their internal resources and external support for social readaptation. One should keep in mind the fact that the impact of negative factors on the unemployed internally displaced persons differs by the cumulative effect, i.e. experienced the impact of one factor, a forced migrant is likely to be affected by others. The model provides for the activities with protective factors that can neutralize the effect of many risks, which forced migrants are subjected to face. In particular, it refers to constructive internal mechanisms of overcoming difficulties, which are manifested in the form of acquired skills and abilities developing during the entire life and helping to get through some challenges (Euwema, 2016).

The third methodology is Nonviolent Communication Model of M. Rosenberg, which is based on the concept of the understanding of personal needs and needs of the people around. According to the model, all people can commiserate and resort to violent or hostile behavior because they don't know other, more effective, strategies to meet needs. Consequently, such a behavior finds expression in the communication through criticism, threats, demands, coercion which distance an individual from a natural state of compassion by causing antipathy towards himself and other people. That kind of communication inflicts deep internal wounds which, in turn, result in dissatisfaction, depression, annoyance, anger and even physical abuse. NVC stipulates the education цям важливо мати уявлення про базові установки, уявлення про картину світу особистості, які в результаті внутрішньої міграції значно змінилися й потребують ретельного розпізнавання та корекції. Виходячи з цього, реабілітаційна робота з безробітними з категорії внутрішньо переміщених осіб була спрямована на подолання стресових станів, особистісний розвиток та інтеграцію їх до нових соціокультурних умов (Сарджвеладзе, 2007).

Ще однією методикою $є$ "Психосоціальна модель розвитку стійкості” М. Еувема, в основу якої покладено поняття “стійкість", яке розглядається як універсальна здатність, що дає змогу людині мінімізувати або подолати негативні наслідки певних життєвих катаклізмів. Незважаючи на всі перипетії в житті вимушених мігрантів, для соціальної реадаптації вони можуть спиратися як на свої внутрішні ресурси, так і на зовнішню підтримку. Варто враховувати той факт, що вплив негативних факторів на безробітних з переліку внутрішньо переміщених осіб вирізняється кумулятивним характером, тобто відчувши на собі вплив одного чинника, вимушений мігрант ймовірно потраплятиме і під дію інших. Зазначена модель передбачає роботу із захисними чинниками, які можуть нейтралізувати дію багатьох ризиків, з якими стикаються вимушені мігранти. Зокрема йдеться про конструктивні внутрішні механізми подолання труднощів, які проявляються у вигляді набутих навичок та здатностей, що розвиваються впродовж життя і допомагають впоратися 3 труднощами (Еувема, 2016).

Третьою методикою $\epsilon$ "Модель ненасильницького спілкування" (NVC-Nonverbal Communication), запропонована М. Розенбергом, яка грунтується на ідеї розуміння особистістю власних потреб і потреб людей, які іï оточують. Згідно з цією моделлю всі люди мають здатність до співчуття, а до насильницької або ворожої поведінки вдаються оскільки не знають інших ефективніших стратегій для задоволення власних потреб. Відповідно, така поведінка проявляється у спілкуванні за допомогою критики, погроз, вимог, примусу, які дистанціюють особистість від природного стану співпереживання, сприяючи виникненню нетерпимості до себе та інших людей. Таке спілкування викликає невдоволення, депресію, роздратування, гнів, а подекуди призводять до фізичного насильства. Модель NVC передбачає навчання особистості максимально зрозуміло й усвідомлено виражати 
of an individual to show four information components most naturally and consciously: observation (without condemnation and accusations), feelings (without considerations), needs (without strategies), request (without demands) and to conceive and comprehend the same components which other people also demonstrate (Rosenberg, 2009).

The analysis of the scientific sources and experience of practical activity towards professional readaptation of unemployed internally displaced persons gives grounds to conclude that the effectiveness of forms, methods and means of complex rehabilitation depends on many factors, as follows: social and psychological characteristics of every individual; the outcome of primary diagnostic examination; determination of mechanisms of behavior under pressure etc. The criteria-performance block embraces the integrated methodology of diagnostics, criteria, indicators and levels of professional readaptation of unemployed internally displaced persons. This block is presented by the components of the phenomenon under study (motivational, stress resilience, behavioral), the levels of rehabilitation (high, average, low) and the result - positive dynamics of professional readaptation of unemployed internally displaced persons.

\section{Conclusions}

Therefore, in the course of the research, the authors develop and substantiate the structural and functional model of professional readaptation of unemployed internally displaced persons. When identifying the positional order of its components, it is found out that, first, it should reflect the sequence of resolving the issue of professional readaptation of internally displaced persons and, second, the reasoning of implementation of correctional and rehabilitation activities with them. It is established that the concept of formation of the structural and functional model consists of the three levels - methodological, theoretical and practical.

The article proves that interaction and interrelations of all defined and characterized blocks (purposeful, theoretical-methodological, conceptual-performance and criteria-perforce) ensure the cohesiveness, integrity and effectiveness of the proposed model of professional readaptation of unemployed internally displaced persons чотири інформаційні компоненти: спостереження (без осуду та звинувачень), почуття (без обдумувань), потреби (без стратегій), прохання (без вимог) - і відповідно сприймати й розуміти ці ж самі компоненти, які транслюють їй інші люди (Розенберг, 2009).

Аналіз наукових джерел і досвіду практичної діяльності з професійної реадаптації безробітних з категорії внутрішньо переміщених осіб дав підстави для висновку, що ефективність форм, методів і засобів комплексної реабілітації залежить від багатьох чинників, а саме: соціально-психологічних характеристик кожної особистості; результатів первинного діагностувального обстеження; визначення механізмів поведінки у стресових ситуаціях тощо. Критеріально-результативний блок охоплює комплексну методику діагностики, критерії, показники та рівні професійної реадаптації безробітних з переліку внутршньо переміщених осіб. Цей блок представлений компонентами досліджуваного феномена (мотиваційним, стресостійким, поведінковим), рівнями реабілітованості (високим, середнім, низьким) і результатом позитивною динамікою професійної реадаптації безробітних із переліку внутрішньо переміщених осіб.

\section{Висновки}

Отже, у процесі дослідження було розроблено й обгрунтовано структурно-функціональну модель професійної реадаптації безробітних, що належать до внутрішньо переміщених осіб, у процесі визначення позиційного розташування компонентів якої з'ясовано, що, по-перше, має відображати послідовність розв'язання проблеми професійної реадаптації безробітних з категорії внутрішньо переміщених осіб, а по-друге, логіку здійснення корекційно-реабалітаційної роботи 3 ними. Визначено, що концепція побудови структурно-функціональної моделі містить три рівні - методологічний, теоретичний і практичний.

Доведено, що взаємодія та взаємозв'язок усіх визначених та схарактеризованих блоків (цільового, теоретико-методологічного, змістоводіяльнісного і критеріально-результативного) забезпечує цілісність, дієвість та ефективність запропонованої моделі професійної реадаптації безробітних, які належать до внутрішньо переміщених осіб, а також спрямована на оптимізацію практичної діяльності фахівців, які здійснюють супровід зазначеної категорії громадян. 
as well as its focus on the optimization of practical activities of the experts mentoring the relevant group of citizens.

The authors consider the detailed characteristics of the volume components of the phenomenon concerned and the description of research-experimental work on professional readaptation of unemployed internally displaced persons as the directions for future research.

\section{References}

Aksenchenko, K. (2018). Socio-psychological factors of professional readaptation of the unemployed in the modern society. Extended abstract of candidate's thesis. Sievierodonetsk: V. Dahl EUNU.

Baklytskyi, I. O. (2008). Labor psychology. Kyiv: Znannia.

Blynova, O. Ye. (2016). Socio-psychological adaptation of forced migrants: approaches and problems of studying the phenomenon of acculturation. Scientific Bulletin of Kherson State University. Series: Psychological Sciences, 3 (1), 111-117.

Drozdova, I. I. (2016). Problems and methods of organizing psychological assistance to forced migrants (from the experience of a psychologist in a public organization). Socio-psychological adaptation of migrants in the modern world: Mater. III International scientific-practical conference. Penza: PGU, 60-64.

Euvema, M. (2016). Psychosocial development of children and youth. Kyiv: "LHSI".

Gaida, J. (2015). Social and Professional Adaptation of Employees as a Main Factor in Shaping Working Conditions. Journal of US-China Public/Administration, 12(10), 789-795.

Maslow, A. H. (1943). A Theory of Human Motivation. Psychological Review, 50 (4), 370-396.

May, R. (1977). The Meaning of Anxiety. N.Y.: Pocket Books.

Orban-Lembryk L. E. (2008). The influence of migration processes on the behavioral manifestations of personality. Collection of scientific works: philosophy, sociology, psychology, 13(1), 3-15.

Roger, C. R. (1942). Counseling and psychotherapy. Cambridge, MA: Riverside Press.

Rozenberg, M. (2009). Language of life. Nonviolent communication. Moscow: Sofija.

Sardzhveladze, N. (2007). Trauma and psychological help. Moscow: Smysl.

Shumeiko, A. P. (2017). Types of readaptation and psychorehabilitation of combatants. Problems of extreme and crisis psychology, 21, 220-229.

Yalom, I. (1980). Existential psychotherapy. New York: Basic Books.
Перспективи подальших досліджень вбачаємо в деталізованій характеристиці компонентного складу досліджуваного феномена і в описі дослідно-експериментальної роботи з проблеми професійної реадаптації безробітних, що належать до внутрішньо переміщених осіб.

\section{Список використаних джерел}

Аксенченко К. Б. Соціально-психологічні чинники професійної реадаптації безробітних в умовах сучасного соціуму: автореф. дис. ... канд. псих. наук: 19.00.05 / Східноукр. нац. ун-т ім. В. Даля. Сєвєродонецьк, 2018. 21 с.

Баклицький I.O. Психологія праці. Київ: Знання, 2008. 316 c.

Блинова 0. Є. Соціально-психологічна адаптація вимушених мігрантів: підходи і проблеми вивчення феномена акультурації. Науковий вісник Херсонського державного університету. Серія: Психологічні науки. 2016. Вип. 3 (1). С. 111-117.

Дроздова И. И. Проблемы и методы организации психологической помощи вынужденным мигрантам (из опыта работы психолога общественной организации). Социальнопсихологическая адаптация мигрантов в современном мире: матер. III Междунар. науч.практ. конф. Пенза: Изд-во ПГУ, 2016. С. 60-64.

Еувема М. Психологічний розвиток дітей та молоді. Київ: “ЛХСІ", 2016. 284 с.

Gajda J. Social and Professional Adaptation of Employees as a Main Factor in Shaping Working Conditions. Journal of US-China Public/Administration, October 2015, Vol. 12, №10, PP. 789-795.

Maslow A. H. A Theory of Human Motivation. Psychological Review, 1943, Vol. 50, №4, PP. 370-396.

May R. The Meaning of Anxiety. N.Y.: Pocket Books, 1977. 234s.

Орбан-Лембрик Л. Вплив міграційних процесів на поведінкові прояви особистості. Збірник наукових праць: філософія, соціологія, психологія. 2008. Вип. 13. Ч. 1, С. 3 - 15.

Rogers C. R. Counseling and psychotherapy. Cambridge, MA: Riverside Press, 1942. 236 c.

Розенберг М. Язык жизни. Ненасильственное общение. Москва: Изд-во София, 2009. 248 с.

Сарджвеладзе Н. Травма и психологическая помощь. Москва6 Смысл, 2007. 268 с.

Шумейко А.П. Види реадаптації і психореабілітації учасників бойових дій. Проблемиекстремальної і кризової психології. 2017. №21, С. 220-229.

Yalom I. (1980). Existential psychotherapy. New York: Basic Books. 322 s. 